\title{
EFEKTIVITAS PUPUK ORGANIK CAIR KULIT ARI KEDELAI UNTUK PERTUMBUHAN TANAMAN SAWI (Brassica juncea L.)
}

\author{
Shelli Aprilia Stanza Ardini ${ }^{*}$, Rachmaniyah, Ferdian Akhmad Ferizqo
}

Jurusan Kesehatan Lingkungan Poltekkes Kemenkes Surabaya

*Email korespondensi: shelliaprilia447@gmail.com

\begin{abstract}
One of the wastes of making tempe is soybean husk which comes from boiling and soaking. Soybean husk waste that is not utilized causes unpleasant odors and pollutes the environment. Utilization as organic fertilizer can be used to overcome the pollution. This study aims to utilize soybean husk waste as a liquid fertilizer applied to mustard greens (Brassica juncea L.).

This type of research is included in the True Experimental Design. With the research design Pretest-Posttest Control Group Design. The object of this research is green mustard (Brassica juncea L.) as many as 30 samples and liquid organic fertilizer from soybean husk waste at concentrations of $5 \%, 10 \%$, and $15 \%$ with 9 replications. The sampling technique used is Simple Random Sampling. Data were obtained from the field in the form of observations and measurements of mustard plant growth parameters including the height of the mustard plant, the number of leaves of the mustard plant, and the diameter of the stem of the mustard plant, the NPK content test in the laboratory, and data analysis was carried out with the Anova test.

The application of liquid organic fertilizer from soybean husks did not significantly affect stem diameter and number of leaves, but did affect plant height. The effective concentration treatment on the growth of mustard greens is a $15 \%$ concentration treatment for plant height with an average of $35.85 \mathrm{~cm}$.

Liquid Organic Fertilizer of soybean epidermis with a concentration of $15 \%$ is effective on the growth of mustard greens. Suggestions for further researchers are to conduct research on other plants with higher concentrations in order to obtain optimal results on plant growth to be studied.
\end{abstract}

Keywords: soybean husk, liquid fertilizer, Natrium, Phosphor, Kalium

\section{PENDAHULUAN}

Kedelai merupakan produk pangan yang memiliki banyak kandungan protein nabati. Kedelai umumnya digunakan sebagai bahan baku olahan seperti susu kedelai, tempe, tahu, kecap, dan berbagai makanan ringan lainnya. Konsumsi kedelai pada tahun 2015 mencapai 2,54 juta ton. Angka tersebut menunjukkan konsumsi langsung oleh penduduk 2,3 juta ton, penggunaan benih 39.000 ton, penggunaan industri non makanan 446.000 ton dan pemanfaatan sebagai susu 49.000 (BPS, 2015).

Kulit ari kedelai merupakan limbah industri pembuatan tempe yang diperoleh dari proses perebusan dan perendaman kacang kedelai. Pemanfaatan kulit ari kedelai ini sebatas sebagai pakan ternak dikarenakan kandungan protein yang cukup tinggi (Iriyani, N., 2019).
Limbahkulit ari kedelai mengandung $86 \%$ karbohidrat, $9 \%$ protein, $4 \%$ abu dan $1 \%$ lemak. Selain itu, kulit ari kedelai juga mengandung asam amino (glisin, asam aspartate, asam glutamate, lisin, serin, leusin, prolin, tirosin, valin, arginine, alanin, isoleusin, fenil alanin, histidin dan metionin) serta beberapa vitamin dan mineral seperti $\mathrm{Fe}, \mathrm{Ca}, \mathrm{K}, \mathrm{P}$, dan Mg (Rachmawati, 2017; Hardiyanti, 2018).

Kandungan protein yang tinggi terdapat pada kulit ari kedelai dapat dijadikan sebagai sumber bahan makanan bagi pertubuhan sumber bahan makanan bagi pertumbuhan mikroorganisme. Sebagai sumber bahan makanan bagi pertumbuhan mikroorganisme. Oleh karena itu limbah itu limbah kulit ari kedelai dapat dijadikan sebagai pupuk organik cair yang berguna untuk 
tanaman. Tanaman yang kekurangan protein dapat menyebabkan tanaman tumbuh kerdil, daun menguning sehingga mengering dan rontok (DP3, 2018).

Sawi hijau adalah jenis sayuran yang sering dikonsumsi oleh masyarakat. Nilai ekonomis tanaman sawi yang sangat tinggi selain tanaman lain seperti brokoli dan kubis (Zulkarnian, 2019). Tanaman sawi hijau dapat tumbuh baik pada tanah yang subur, gembur. Keuntungan lainnya adalah tanaman ini mudah mengikat air dan kaya bahan organik (Istarofah \& Zuchrotus Salamah, 2017).

Penggunaan pupuk organik padat maupun cair pada tanaman sangat berperan dalam pertumbuhan. Dosis dalam pemberian pupuk organik juga perlu diperhatikan (Marpaung, 2014). Penelitian penggunaan pupuk organik cair air sabut kelapa pada konsentrasi $5 \%$ berperan terhadap pertumbuhan dan hasil kentang kleci. Oleh karena itu pada penelitian ini menggunakan konsentrasi $5 \%, 10 \%$ dan $15 \%$ yang digunakan dalam aplikasi penggunaan pupuk organik cair terhadap pertumbuhan tanaman sawi hijau (Suripto, dkkk., 2018).

Berdasarkan penelitian yang dilakukan oleh Supriyatin dan Pratiwi (2019) menunjukkan bahwa pupuk organik cair yang berasal dari limbah bakpia dan pembuatan tempe sebanyak $60 \mathrm{ml} / \mathrm{L}$ berpengaruh terhadap pertumbuhan tanaman sawi (Brassica rapa L.) pada parameter jumlah daun, berat basah,dan kadar klorofil.

Industri tempe yang terletak di Jalan Kupang tembusan II merupakan home industri tempe yang didirikan oleh Jarwo Susanto.Industri tersebut dalam sehari menghasilkan limbah padat tempe sebanyak $25 \mathrm{~kg} /$ hari sehingga dapat mencemari lingkungan di sekitarnya. Limbah padat tempe yang dihasilkan salah satunya adalah kulit ari kedelai. Pada industri tersebut menghasilkan limbah kulit air kedelai sebanyak 22 liter atau setara dengan 1 ember besar per hari yang tidak dimanfaatkan atau dibuang begitu saja. Oleh karena itu, perlu dilakukan pemanfaatan dari limbah kulit ari kedelai yaitu dijadikan sebagai pupuk organik cair. Maka dari itu tujuan penelitian ini adalah untuk mengetahui efektifitas pupuk organik cair limbah kulit ari kedelai untuk pertumbuhan tanaman sawi hijau.

\section{METODE PENELITIAN}

Penelitian ini berjenis eksperimen dengan desain penelitian Pretest-Posttest Control Group Desain untuk membandingkan efektifitas pupuk organik cair konsentrasi $5 \%, 10 \%$, dan $15 \%$ terhadap pertumbuhan tanaman sawi. Objek penelitian ini adalah pertumbuhan tanaman sawi yang meliputi tinggi tanaman, jumlah daun, dan diameter batang. Dalam penelitian temperatur, $\mathrm{pH}$, suplai air, dan volume pemberian pupuk dilakukan kontrol untuk menghindari bias. Tanaman sawi hijau yang digunakan sebanyak 30 sampel dengan 9 kali replikasi perlakuan per konsentrasi pupuk organic cair. Teknik sampling yang digunakan Simple Random Sampling. Data diperoleh dari pengamatan pertumbuhan tanaman sawi dan uji kandungan NPK di laboratorium. Analisis data menggujakan uji Anova dan dideskripsikan dalam pembahasan.

\section{HASIL DAN PEMBAHASAN}

Penelitian ini berlangsung selama 4 minggu yaitu 2 minggu untuk fermentasi pupuk organik cair dan 2 minggu untuk pengamatan parameter pertumbuhan pada tanaman sawi hijau yaitu tinggi, diameter batang, dan jumlah daun. Langkah kerja dalam pembuatan pupuk organik cair dari limbah kulit ari kedelai yaitu mempersiapkan alat dan bahan yang akan digunakan. Kemudian limbah kulit ari kedelai ditimbangsebnayak $2 \mathrm{~kg}$. Setelah itu ditambahkan EM4 sebanyak 2 liter, gula merah $0,5 \mathrm{~kg}$ dilarutkan dalam ember yang telah diisi 3 liter air kemudian aduk hingga rata. Kulit ari kedelai yang sudah tercampur rata dengan menambahkan EM4, gula merah, dan air diaduk kembali hingga tercampur rata dan ditutup rapat untuk proses fermentasi. Fermentasi dilakukan selama 14 hari. Pupuk yang berasal dari hasil proses fermentasi diaduk lalu disaring dan dimasukkan ke dalam botol untuk siap digunakan. 


\section{Uji Kandungan NPK}

Tabel 1

Hasil Uji Kandungan NPK

\begin{tabular}{cccc} 
No & Jenis Parameter & Hasil Uji Pada Lab(\%) & Persyaratan (\%) \\
\hline 1 & Unsur Hara Nitrogen & 0,338 & $6 \%$ \\
\hline 2 & Unsur Hara Phospat & 0,752 & $6 \%$ \\
\hline 3 & Unsur Hara Kalium & 1,617 & $3-6 \%$ \\
\hline
\end{tabular}

Diatas menunjukkan bahwa hasil dari uji kandungan NPK dengan satu sampel yaitu pupuk organik cair dari limbah kulit ari kedelai pada laboratorium yaitu $\mathrm{N}$ didapat hasil sebanyak $0,338 \% \quad P$ sebanyak 0,752 , dan $\mathrm{K}$ sebanyak $1,617 \%$ dari hasil uji kandungan NPK. Menurut Peraturan Menteri Pertanian Nomer 70 Tahun 2011 Tentang Pupuk Organik, Pupuk Hayati, dan Pembenah Tanah bahwa untuk standar uji kandungan $\mathrm{N}$ adalah $6 \%$, P sebanyak $6 \%$, dan $\mathrm{K}$ sebanyak 3-6\% akan tetapi untuk hasil uji kandungan yang didapatkan sebanyak $0,338 \%$, $P$ sebanyak 0,752 , dan $K$ sebanyak $1,617 \%$ sehingga dapat disimpulkan pupuk organik cair belum memenuhi syarat pada standar yang berlaku.

Beberapa faktor yang mempengaruhi pupuk organik cair tidak memenuhi syarat yaitu ukuran bahan yang akan dijadikan sebagai pupuk organik cair dan rendaman kulit kedelai. Pada penelitian ini pada saat membuat pupuk organik cair limbah kulit ari kedelai tidak di cacah atau dipotong sehingga proses pengomposannya tidak sempurna yang menyebabkan untuk hasil uji kandungan NPK belum memenuhi syarat sesuai dengan peraturan yang berlaku.

Hal ini sesuai dengan penelitian Parintak (2018) yang menyatakan bahwa kandungan nitrogen yang cukup pada tanaman maka kandungan hara lainnya seperti fosfor akan meningkat untuk mengimbangi laju pertumbuhan tanaman dengan cepat. Kandungan nitrogen dan fosfor sangat berpengaruh terhadap pertumbuhan tanaman sawi hijau. Jadi semakin banyak jumlah daun, maka tempat untuk berfotosintesis lebih banyak dan hasilnya juga semakin meningkat.

\section{Pengukuran Parameter Pertumbuhan Tinggi tanaman}

Tabel 2

Rata-Rata Tinggi Tanaman Sawi Hijau (Brassica Juncea L)

\begin{tabular}{ccccccc}
\hline \multirow{2}{*}{ Pengulangan } & \multicolumn{7}{c}{ Perlakuan } \\
\cline { 2 - 7 } & $\mathbf{5}$ \% & $\mathbf{1 0} \%$ & $\mathbf{1 5} \%$ & $\mathbf{K 1}$ & $\mathbf{K 2}$ & $\mathbf{K 3}$ \\
\hline 1 & 29,8 & 28,9 & 44,8 & 29,4 & 26,6 & 27,9 \\
\hline 2 & 25,8 & 33,8 & 39,1 & 33,3 & 22,9 & 35,1 \\
\hline 3 & 24,4 & 25,2 & 27,6 & 34,5 & 28,5 & 34,9 \\
\hline 4 & 28,5 & 31,6 & 31,5 & & & \\
\hline 5 & 29,4 & 25,2 & 33,9 & & & \\
\hline 6 & 27,9 & 28,2 & 34,8 & & & \\
\hline 7 & 33,6 & 28,9 & 36,7 & & & \\
\hline 8 & 34,5 & 32,3 & 36,1 & & & \\
\hline 9 & 38,2 & 34,7 & 38,2 & & & \\
\hline Rata-Rata & $\mathbf{3 0 , 2 3}$ & $\mathbf{2 9 , 8 6}$ & $\mathbf{3 5 , 8 5}$ & $\mathbf{3 2 , 4}$ & $\mathbf{2 6}$ & $\mathbf{3 2 , 6 3}$ \\
\hline
\end{tabular}

Diatas menunjukkan bahwa rata-rata pertumbuhan tinggi pada tanaman sawi hjau pada setiap perlakuan memiliki perbedaan. Pertumbuhan tinggi tanaman sawi hijau. Tertinggi ditunjukkan pada perlakuan konsentrasi $15 \%$ dengan ratarata yaitu $35,85 \%$, konsentrasi $5 \%$ dengan rata-rata yaitu $30,23 \%$, 
konsentrasi $10 \%$ dengan rata-rata yaitu 29,86, sedangkan untuk pertumbuhan yang paling tinggi pada perlakuankontrol adalah pada kontrol 3 dengan rata-rata yaitu $32,63 \%$, pertumbuhan sedang ada pada perlakuan kontrol 1 dengan ratarata yaitu $32,4 \%$, dan untuk pertumbuhan yang paling rendah ditunjukkan pada perlakuan kontrol 2 dengan rata-rata yaitu $26 \%$. Pada tabel diatas menunjukkan hasil dari kontrol hanya 3 kali pengulangan karena kontrol nya hanya 3 sehingga pengulangan juga3 kali saja untuk hasil pengamatan.

Uji anova menunjukkan $\mathrm{p}$ value (sig) $=0,012>0,05$ yang dapat disimpulkan bahwa pupuk organik cair limbah kulit ari kedelai berpengaruh terhadap pertumbuhan tinggi tanaman sawi hijau. Berdasarkan dari hasil analisis uji ANOVA data pertumbuhan tinggi tanaman sawi hijau menunjukkan nilai yang signifikan. Hal ini menjelaskan bahwa penggunaan pupuk organik cair limbah kulit ari kedelai pada tanaman sawi hijau dapat mempengaruhi secara nyata. Pemberian pupuk organik cair pada konsentrasi $15 \%$ menunjukkan bahwa rata-rata tinggi tanaman paling tertinggi dengan rata rata yaitu $35,85 \mathrm{~cm}$. Kandungan unsur hara yang terdapat pada pupuk organik cair telah mencukupi kebutuhan unsur hara pada tanaman, maka akan tercukupi pertumbuhan tinggi tanaman sawi hijau menjadi optimal. Hal ini sejalan dengan pendapat yang disampaikan oleh (Daryadi, 2017) bahwa tersedianya unsur hara yang mencukupi dapat memberikan pertumbuhan tinggi tanaman secara optimal.

\section{Diameter Batang}

Tabel 3

Rata-Rata Diameter Batang Tanaman Sawi Hijau (Brassica juncea L.)

\begin{tabular}{ccccccc}
\hline & \multicolumn{7}{c}{ Perlakuan } \\
\cline { 2 - 7 } Pengulangan & $5 \%$ & $10 \%$ & $15 \%$ & $\mathrm{~K} 1$ & $\mathrm{~K} 2$ & $\mathrm{~K} 3$ \\
\hline 1 & 8,2 & 3,6 & 6,3 & 2,5 & 2,3 & 2,7 \\
\hline 2 & 10,6 & 4,6 & 7,2 & 3,8 & 5,6 & 5,4 \\
\hline 3 & 10,2 & 4,3 & 8,7 & 3,8 & 2,1 & 3,7 \\
\hline 4 & 12,4 & 7,5 & 12,9 & & & \\
\hline 5 & 11,2 & 4,7 & 14,8 & & & \\
\hline 6 & 9,8 & 4,6 & 13,7 & & & \\
\hline 7 & 8,5 & 8,3 & 13,6 & & & \\
\hline 8 & 9,7 & 9,1 & 21,9 & & & \\
\hline 9 & 13,1 & 10,4 & 19,5 & & & \\
\hline Rata-Rata & $\mathbf{1 0 , 4 1}$ & $\mathbf{6 , 3 4}$ & $\mathbf{1 3 , 1 7}$ & $\mathbf{3 , 3 6}$ & $\mathbf{3 , 3 3}$ & $\mathbf{3 , 9 3}$ \\
\hline
\end{tabular}

$\mathrm{Di}$ atas menunjukkan bahwa hasil batang, pertumbuhan diameter batang pengamatan langsung di lapangan tanaman sawi hijau memiliki nilai yang menunjukkan bahwa rata-rata pertumbuhan diameter batang pada tanaman sawi hjau. pada setiap perlakuan memiliki perbedaan. Pertumbuhan tinggi tanaman sawi hijau yang paling tinggi ditujukkan pada perlakuan konsentrasi $15 \%$ dengan ratarata yaitu $13,17 \mathrm{~cm}$, konsentrasi $5 \%$ dengan rata-rata yaitu $30,23 \mathrm{~cm}$, konsentrasi $10 \%$ dengan rata-rata yaitu 29,86 cm. Hasil uji Anova menunjukkan bahwa $\mathrm{p}$ value $(\mathrm{sig})=0,000<0,05$ yang berarti pupuk organik cair limbah kulit ari kedelai tidak tidak berpengaruh terhadap pertumbuhan diameter batang tanaman sawi hijau. Berdasarkan dari hasil analisis uji anova pada rata-rata diameter tidak signifikan yang berarti penggunaan pupuk organik cair kulit ari kedelai tidak berpengaruh yang nyata terhadap pertumbuhan diameter batang paada tanaman sawi hijau. Hal ini disebabkan oleh beberapa penggunaan media tanaman dan pupuk organik cair tidak mempengaruhi atau sama lain sehingga satu perlakuan dengan yang lain tidak memperlihatkan suatu reaksi. Menurut (Hadisuwito, 2012) tanaman yang kekurangan usur $\mathrm{N}$ dan $\mathrm{P}$ dapat menyebabkan mengecilnya daun dan batang tanaman sehingga hal tersebut yang menyebabkan pertumbuhan tanaman pada diameter batang tidak sempurna. 
Jumlah Daun

Tabel 4

Rata-Rata Jumlah Daun Tanaman Sawi Hijau

\begin{tabular}{ccccccc}
\hline & \multicolumn{7}{c}{ Perlakuan } \\
\cline { 2 - 7 } Pengulangan & $\mathbf{5 \%}$ & $\mathbf{1 0} \%$ & $\mathbf{1 5} \%$ & $\mathbf{K 1}$ & $\mathbf{K 2}$ & $\mathbf{K 3}$ \\
\hline 1 & 6 & 9 & 7 & 8 & 8 & 8 \\
\hline 2 & 7 & 9 & 7 & 6 & 13 & 7 \\
\hline 3 & 8 & 7 & 10 & 8 & 8 & 10 \\
\hline 4 & 5 & 8 & 8 & & & \\
\hline 5 & 6 & 10 & 9 & & & \\
\hline 6 & 8 & 7 & 8 & & & \\
\hline 7 & 13 & 8 & 6 & & & \\
\hline 8 & 9 & 5 & 7 & & & \\
\hline 9 & 7 & 5 & 6 & & $\mathbf{8 3}$ \\
\hline Rata-Rata & $\mathbf{7 , 6 6}$ & $\mathbf{7 , 5 5}$ & $\mathbf{7 , 5 5}$ & $\mathbf{7 , 3 3}$ & $\mathbf{9 , 6 6}$ & \\
\hline
\end{tabular}

Di atas menunjukkan bahwa dari hasil pengamatan langsung di lapangan menunjukkan bahwa rata-rata pertumbuhan jumlah daun pada tanaman sawi hjau pada setiap perlakuan memiliki perbedaan. Pertumbuhan jumlah daun tanaman sawi hjau yang paling tinggi ditunjukkan pada perlakuan konsentrasi $5 \%$ dengan rata- rata yaitu $7,66 \mathrm{~cm}$, konsentrasi $10 \%$ dengan rata-rata yaitu $7,55 \mathrm{~cm}$, konsentrasi $15 \%$ dengan ratarata yaitu $7,55 \mathrm{~cm}$. Uji anova menunjukkan bahwa $\mathrm{p}$ value (sig) $=0,876>0,05$ yang berarti pupuk organik cair limbah kulit ari kedelai tidak berpengaruh terhadap pertumbuhan jumlah daun tanaman sawi hijau.

\section{KESIMPULAN}

Hasil dari uji kandungan unsur hara $(\mathrm{N}, \mathrm{P}$, dan K) pada laboratorium menunjukkan belum memenuhi syarat yang sesuai dengan peraturan berlaku yaitu $\mathrm{N}$ sebanyak 3-6\%, P sebanyak 3-6\%, dan K sebanyak $3-6 \%$. Rata-rata yang paling tinggi didapatkan hasil dari rata-rata paramater pertumbuhan yaitu tinggi tidak signifikan yang artinya bahwa tidak ada pengaruh yang nyata terhadap pertumbuhan jumlah daun tanaman.

Hasil dari penelitian ini bahwa penggunaan pupuk organik cair dari limbahkulit ari kedelai yang paling efektif terhadap jumlah daun pada konsentrasi $5 \%$ dengan rata-rata yaitu $7,66 \mathrm{~cm}$. Hal ini menunjukkan bahwa pada konsentrasi $5 \%$ memiliki kandungan unsur hara yang sesuai dengan yang dibutuhkan oleh tanaman.

\section{SARAN}

Limbah kulit ari kedelai dapat digunakan sebagai pupuk organik cair dan padat untuk pertumbuhan tanaman. Peneliti lain dapat melanjutkan penelitian dengan konsentrasi yang lebih tinggi dengan memperhatikan faktor pertumbuhan tanaman yang lainnya.

\section{DAFTAR PUSTAKA}

Badan Pusat Statistik. (2015). Statistik Tanaman Buah-buahan dan Sayuran Tahunan Indonesia. https://www.bps.go.id/. Diakses pada April 2019.

Dinas Pangan, Pertanian, dan Perikanan. (2018). Unsur Hara Kebutuhan Tanaman. Pontianak.

https://pertanian.pontianakkota.go id/artikel/52-unsur-harakebutuhan-tanaman.html (Diakses 06 Desember2020).

Hardiyanti. (2018). Pemanfaatan Media Kulit Ari Kedelai Terhadap Pertumbuhan Jamur Candida Albicans dan Aspergillus sp. Semarang: Universitas Muhammadiyah Semarang.

Iriyani, N. (2019). Pengaruh penggunaan kulit biji kedelai sebagai pengganti jagung dalam ransum terhadap kecernaan energi, protein dan kinerja domba. Animal Production. Journal Produksi Ternak. Vol. 2

Istarofah, \& Salamah, Z. (2017). Pertumbuhan Tanaman Sawi Hijau (Brassica Juncea L.) Dengan Pemberian Kompos Berbahan Dasar Daun Paitan (Thitonia 
diversifolia). Bio-site,3(1), 39-46

Marpaung, Agustina. (2014). Pemanfaatan Pupuk Organik Padat dan Pupuk Organik Cair dengan Pengurangan Pupuk Anorganik Terhadap Pertumbuhan Tanaman Jagung. Jurnal Saintech. Vol.6. ISSN No. 20869681. Hal: 8-15.

Peraturan Menteri Pertanian No 70 Tahun 2011 Tentang Pupuk Organik, Pupuk Hayati, Dan Pembenah Tanah.

Rachmawati. (2017). Kajian

Vermicomposting Limbah Kulit Ari Biji Kedelai Sebagi Pupuk Organik. SENASPRO.
Suripto,W.,Purwani, T.,Nugroho, B., (2018). Pengaruh Konsentrasi Pupuk Organik Cair Sabut Kelapa Terhadap Pertumbuhan dan Hasil Kentang Kleci

Widodo Suripto, Tyastuti Purwani, Bambang Nugroho. (2018).

Pengaruh Konsentrasi Pupuk Dan Hasil Kemtang Kleci. Jurnal Fps UNS. 2 (1). Organik Cair Sabut Kelapa Terhadap Pertumbuhan

Zulkarnain (2019).Pupuk Organik Cair Limbah Tahu Untuk Tanaman Sawi Hijau (Brassica juncea L.).Yogyakarta:Universitas Atma Jaya. 